\title{
Utilization of information technology in the implementation of active learning in Muhammadiyah Private Schools 21 Dolok Batu Nanggar online
}

\author{
Tulus $^{1 *}$, Saib Suwilo ${ }^{1}$, T.J. Marpaung ${ }^{1}$, Elviwani ${ }^{2}$, \\ ${ }^{1}$ Department of Mathematics, Faculty Science and Mathematics, Universitas Sumatera Utara, \\ Medan, Indonesia \\ ${ }^{2}$ Department of Computer, Faculty of Information and Technology, Universitas Sumatera \\ Utara, Medan, Indonesia \\ *Email: tulus@usu.ac.id
}

\begin{abstract}
In general, junior high school students view mathematics as a difficult and boring subject. In addition to students, teachers also experience difficulties in delivering material, including time constraints in delivering quite a lot of material, and a lack of student interest in learning mathematics when using conventional learning methods such as from textbooks and explanations from the teacher. With these considerations, the proposer wants to apply knowledge and technology by making mathematics learning media tutorials so that they can increase understanding and attract students' interest in learning and help improve the quality of mathematics education and teaching. The result achieved is that community service for active learning and ICT should be reproduced because there are still many schools that have not implemented it. Meanwhile, from the progress of the times, namely Industry 4.0, ICT-based learning is very much needed.
\end{abstract}

Keywords: Online, Information Technology, Community Service

\begin{abstract}
Abstrak
Secara umum siswa Sekolah Menengah Pertama memandang pelajaran matematika adalah pelajaran yang sulit dan membosankan. Selain siswa, guru juga mengalami kesulitan dalam menyampaikan materi, diantaranya keterbatasan waktu dalam menyampaikan materi yang cukup banyak, dan kurangnya ketertarikan siswa belajar matematika apabila menggunakan metode pembelajaran konvensional seperti dari buku pelajaran dan penjelasan dari guru. Dengan pertimbangan ini pengusul ingin mernerapkan pengetahuan dan teknologi dengan mengadakan pembuatan dan tutorial media pembelajaran matematika sehinggadapat meningkatkan pemahaman dan menarik minat belajar siswa sertta membantu meningkatkan mutu pendidikan dan pengajaran matematika. Hasil yang dicapai adalah pengabdian masyarakat untuk pembelajaran aktif dan TIK sebaiknya diperbanyak dikarenakan masih banyak sekolah yang belum menerapkannya. Sedangkan dari kemajuan zaman yaitu Industri 4.0, pembelajaran berbasis TIK sangat diperlukan
\end{abstract}

Kata Kunci: Daring, Teknologi Informasi, Pengabdian

\section{PENDAHULUAN}

Kegiatan Pengabdian kepada Masyarakat ini akan dilakukan di SMP Swasta Muhammadiyah - 21 Dolok Batu Nanggar, yang berlokasi di Jalan Merdeka No 16 Serbelawan, Kecamatan Dolok Batu Nanggar, Kabupaten Simalungun, Provinsi Sumatera Utara. Jarak dari Universitas Sumatera Utara ke SMP ini adalah 109,3Km, yang melintasi jalan lintas Sumatra, dari Medan menuju kearah Pematang Siantar. Sesampai di jalan Serbelawan membelok kiri ke jalan Merdeka Serbalawan kemudian kira-kira 3,5Km tujuan ada di sebelah kanan. Secara umum siswa Sekolah Menengah Pertama memandang pelajaran matematika adalah pelajaran yang sulit dan membosankan. Selain siswa, guru juga mengalami kesulitan dalam menyampaikan materi, diantaranya keterbatasan waktu dalam menyampaikan materi yang cukup banyak, dan kurangnya ketertarikan siswa belajar 
matematika apabila menggunakan metode pembelajaran konvensional seperti dari buku pelajaran dan penjelasan dari guru saja. Oleh karena itu perlu diusahakan dalam proses pembelajaran matematika harus lebih menarik lebih interaktif dan menyenangkan.

Dalam dunia komputer dikenal istilah animasi. Animasi merupakan salah satu bagian grafika komputer yang menyajikan tampilan yang sangat atraktif. Pemanfaatan animasi dapat ditujukan untuk similasi, menarik perhatian pemakai computer pada bagian tertentu pada layar, menampilkan keluaran program dengan gambar-gambar yang menarik dibandingkan dengan sederetan angka atau huruf. Dengan adanya aplikasi ini diharapkan dapat memudahkan dam menyenangkan dalam memahami dan mempelajari materi yang diberikan.

Penggantian sistem ini diharapkan dapat memberikan informasi yang akurat, menghemat biaya dan waktu, sehingga dalam proses belajar mengajar seluruh siswa dapatmengerti materi pelajaran tersebut. Begitu juga perancangan animasi ini dapat memberikan motivasi terhadap siswa dalam hal pembelajaran matematika khususya masalah bangun bidang dan ruang.

\section{METODE PELAKSANAAN}

Untuk menyelesaikan masalah yang telah diuraikan dalam Bab I, dilakukan perlatihan kepada guru dan dipraktekkan ke siswa di Sekolah. Guru dilatih membuat bahan ajar yang dikemas menggunakan media Teknologi Informasi dan Komunikasi. Suatu Sistem informasi yang interaktif dan task oriented tentang aplikasi pembelajaran matematika.

Setelah melakukan kegiatan, diharapkan akan tersedia bahan ajar, dan pedoman menyusun bahan ajar yang menarik dan pembelajaran menjadi aktif. Selain itu akan ditulis sebuah artikel ilmiah tentang pembuatan bahan ajar matematika SMP yang menarik dan siswa menjadi aktif. Metode pelaksanaan berisi metode-metode pelaksanaan yang sesuai teori dari buku ataupun artikel yang disitasi. Sitasi dilarang menggunakan akses dari sebuah website. Metode dituliskan secara rinci dan jelas. Jika perlu bisa digambarkan diagram alir untuk metode pelaksanaan sama dengan aturan untuk membuat diagram alir dari suatu algoritma.

Pelaksanaan Pengabdian ini akan dilakukan dalam dua tahapan besar, yaitu:

1. Pelatihan Penyiapan Rencana Proses Pembelajaran dan Pembuatan Bahan Ajar berbasis Teknologi Informasi.

2. Pelatihan kegiatan belajar mengajar secara Daring

Diperkirakan kegiatan ini akan dilaksanakan pada Bulan Juli 2020 sebelum tahun ajaran baru dimulai.

Metode yang akan dilakukan pada pelaksanaan pengabdian ini adalah :

1. Mendapatkan data yang berupa informasi yang diambil dari buku atau kurikulum pelajaran matematika khusus materi yang akan dibuat aplikasi pembelajaran nya.

2. Melakukan identifikasi bagaimana membuat agar materi yang dikaji menjadi lebih mudah dipelajari oleh siswa SMP.

3. Untuk menarik minat belajar siswa pada materi ini, akan dibuat aplikasi pembelajaran yang materinya dikemas seefisien mumgkin, sehingga siswa dapat berinteraksi dengan aplikasi tersebut.

4. Melakukan perancangan aplikasi pembelajaran, mulai dari membuat tampilan aplikasi, penyusunan materi, latihan dan soal.

5. Setelah perancangan rampung dan diperoleh hasil yang maksimal, maka dilakukan pembagian aplikasi ini ke sekolah dan membuat pelatihan /workshop kepada guru matematika atau siswa.

\section{HASIL DAN PEMBAHASAN}

Pada pelaksanaan pengabdian yang telah dilaksanakan pada hari sabtu 15 agustus 2020 di SMP Swasta Muhammadiyah 21 Dolok Batu Nanggar yaitu kunjungan tim pengabdian sebanyak 2 kali yaitu kunjungan tim pengabdian pada hari sabtu 11 juli 2020 dengan agenda forum group 
discussion (FGD) yang membahas terkait isu yang sedang berkembang di lingkungan sekolah dan rencana program yang akan dilaksanakan demi menjawab persoalan yang sedang dihadapi oleh sekolah terutama terkait pembelajaran secara daring dalam menghadapi tatanan pembelajaran baru secara jarak jauh (PJJ). Selanjutnya kunjungan kedua pada hari sabtu 15 agustus 2020 dilaksanakan pelatihan pembelajaran secara daring kepada guru dan staff tata usaha SMP Swasta Muhammadiyah 21 Dolok Batu Nanggar. Demi mendukung proses pelatihan pembelajaran secara daring tim pengabdian memberikan beberapa sarana dan prasarana berupa laptop, media penyimpanan flashdisk, dan beberapa peralatan pendukung yang dibutuhkan SMP Swasta Muhammadiyah 21 Dolok Batu Nanggar.

\subsection{Focus Group Discussion (FGD)}

Kegiatan FGD bertujuan untuk melakukan diskusi awal dalam mempelajari dan mengetahui perkembangan sekolah didalam melaksanakan pembelajaran untuk siswa/i di SMP Swasta Muhammadiyah 21 Dolok Batu Nanggar. Kegiatan dihadiri oleh Kepala Sekolah SMP Swasta Muhammadiyah 21 Dolok Batu Nanggar, Guru, pegawai Tata Usaha, dan Orang tua murid. Kegiatan dibuka oleh ketua Tim Pengabdian Pada Masyarakat dan di bawakan oleh anggota Tim pengabdian pada masyarakat.

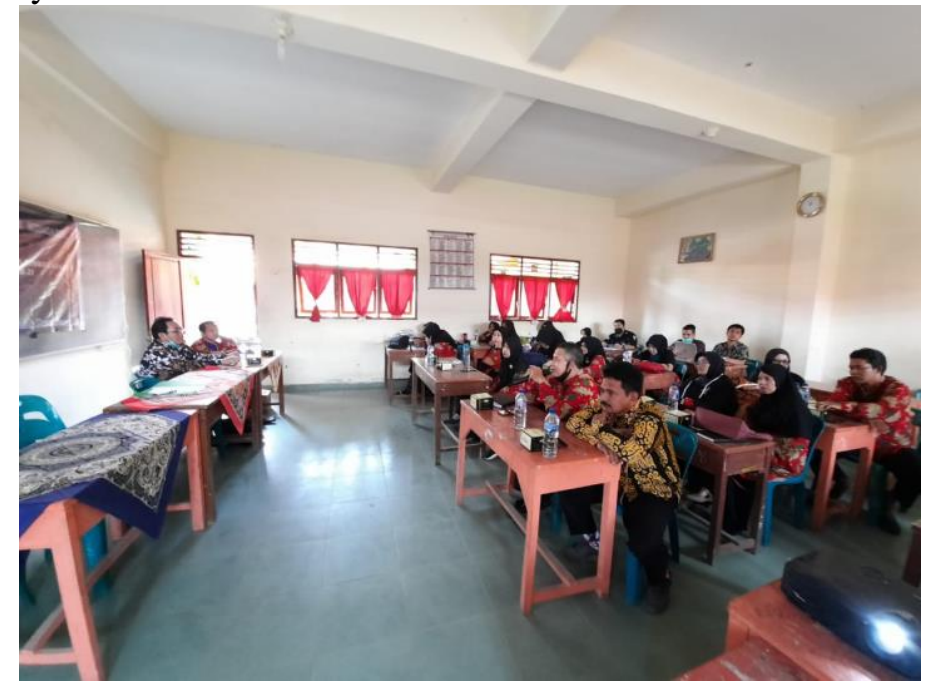

Gambar 3.1 Kata Sambutan Ketua Pengabdian USU

\subsection{Pelatihan Pembelajaran Aktif di Sekolah}

Pada tahap kedua telah dilakukan pelatihan di dalam pelatihan pembelajaran aktif di sekolah secara daring yang ditujukan kepada guru dan staf SMP Swasta Muhammadiyah 21 Dolok Batu Nanggar. Pelatihan dipimpin langsung oleh ketua Tim dalam memberikan metode pembelajaran yang berbeda yang dapat di terapkan kepada siswa/i di sekolah. Pelatihan yang dilakukan diharapkan mampu memberikan edukasi kepada para guru supaya tidak melupakan nilai-nilai yang harus dilakukan disetiap kegiatan belajar mengajar yang akan dilakukan seperti mengucap salam, berdoa, menyanyikan lagu bernuansa Nasionalisme dan nilai-nilai Pancasila ditengah-tengah kehidupan bermasyarakat. 


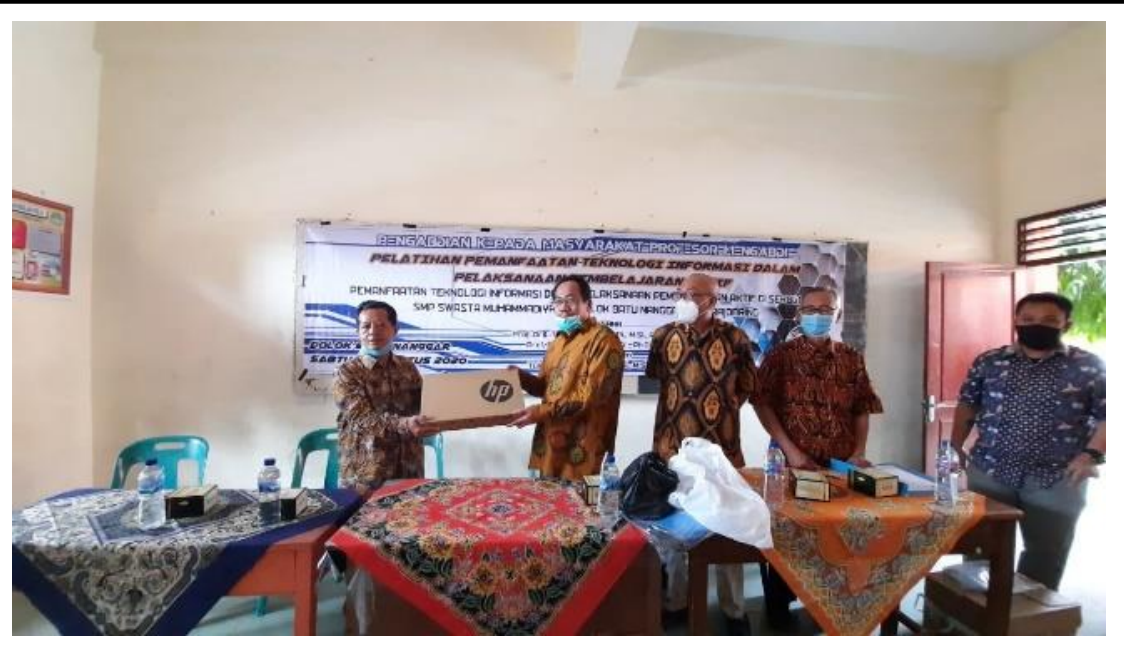

Gambar 3.2. Serah Terima Perangkat Pendukung Pembelajaran Aktif di Sekolah

\section{KESIMPULAN}

Dari semua kegiatan pengabdian kepada masyarakat yang dilakukan dapat disimpulkan bahwa kegiatan ini sangat penting dilakukan karena banyak hal positif yang dihasilkan. Dari kegiatan pertama yaitu Focus Group Discussion diperoleh banyak masukan dan saran dalam memperbaiki keadaan pendidikan di Indonesia. Tetapi banyak hambatan yang membuat setiap saran dapat terlambat dalam pelaksanaanya. Sarana dan prasarana yang kurang memadai dalam melakukan kegiatan belajar dan mengajar. Serta keterlibatan alumni dalam membantu membangun dan mengembangkan SMP Swasta Muhammadiyah 21 Dolok Batu Nanggar.

Untuk kegiatan kedua yaitu pemberian materi pembelajaran aktif serta pemberian sarana pembelajaran sesuai hasil FGD dapat dilihat keinginan untuk mengembangkan sekolah sangat tinggi. Dapat dilihat dari keinginan belajar guru dan staf supaya dapat menerapkan pembelajaran aktif di SMP Swasta Muhammadiyah 21 Dolok Batu Nanggar. Dan dilanjutkan kegiatan pemberian materi untuk menerapkan pembelajaran aktif berbasis teknologi informasi dan komunikasi untuk menyempurnakan pembelajaran aktif berbasis TIK.

Dari kedua kegiatan tersebut, kesimpulan yang dapat diambil adalah kegiatan pengabdian masyarakat untuk pembelajaran aktif dan TIK sebaiknya diperbanyak dikarenakan masih banyak sekolah yang belum menerapkannya. Sedangkan dari kemajuan zaman yaitu Industri 4.0, pembelajaran berbasis TIK sangat diperlukan. Saran untuk pengabdian berikutnya yaitu pembelajaran berbasis TIK bisa dibuat dengan suatu program supaya lebih memberikan bentuk ilmu pengetahuan.

\section{UCAPAN TERIMAKASIH}

Artikel ini merupakan salah satu hasil dari Program Pengabdian kepada Masyarakat yang Dibiayai oleh dana NON PNBP Universitas Sumatera Utara dengan nomor 291/UN5.2.3.2.1/PPM/2020. Oleh karena itu, diucapkan terimakasih kepada Rektor USU dan LPPM USU yang telah memberikan dana pengabdian tahun 2020 Skema Profesor mengabdi. Terima kasih juga kepada Mitra pada kegiatan pengabdian ini. 


\section{DAFTAR PUSTAKA}

HomeEdition. 2005, Macromedia flash Profesional 8 help, Macromedia Inc

Juhaeri. 2009. Pengantar Multimedia untuk Media Pembelajaran bagian I, Ilmu Komputer.

Retno, Margono dan Bambang Eka Purnama. ISSN 1979 - 9330. Study of Interaktif Recognition Letter and Number For Children With Computer Multimedia. Indonesian jurnal on Computer Science - Speed (IJCSS) 4 Vol. 3 Nomor 1 Agustus 2008

Script Island. 2008. Panduan Mudah Membuat Animasi. Jakarta: Media Kita.

Tulus, Sawaluddin, T.J. Marpaung, dan M.R. Syahputra. 2018. Making Learning Teaching Materials in School Based On Information And Communication Technology. Abdimas Talenta. Vol. 3 No. 2 pp. 202-2016 